\title{
Idiopathic pulmonary fibrosis: accurate diagnosis and early treatment
}

\author{
António Morais ${ }^{1,2, a}$
}

Idiopathic pulmonary fibrosis (IPF) poses the greatest diagnostic challenge in the general context of interstitial lung diseases and, in particular, regarding interstitial pneumonias. ${ }^{(1-4)}$ That is due to the clinical, imaging and histological overlapping with other chronic fibrosing pneumonias in which the pattern of usual interstitial pneumonia (UIP) may occur, as in the case of chronic hypersensitivity pneumonitis or connective tissue diseases. ${ }^{(1,4)}$ A Fleischner Society document ${ }^{(5)}$ defines the imaging diagnosis of IPF in cases with the presence of typical UIP and advocates the same diagnosis in cases of probable UIP only when there is no clinical indicator regarding environmental exposure or autoimmunity that would suggest the presence of another chronic fibrosing pneumonia. In such cases, the diagnostic work-up should proceed with the performance of a pulmonary biopsy. ${ }^{(5)}$ The rigor of that evaluation protocol aligns the document ${ }^{(5)}$ with international guidelines published in 2011, ${ }^{(1)}$ which also recommend a more interventional strategy involving BAL and surgical lung biopsy in cases of probable UIP. Within the investigation of differential diagnosis of IPF, as is shown in this issue of the $\mathrm{JBP}_{,}^{\left({ }^{(6)}\right.}$ researching the family context is highly relevant because that type of fibrosis tends to have a different evolution and therapeutic response profile, so any family relationship should always be documented in the diagnosis of interstitial lung disease.

In 2014, the results of two clinical trials of two different medications, pirfenidone ${ }^{(7)}$ and nintedanib, ${ }^{(8)}$ demonstrated a positive impact on the evolution of IPF by significantly reducing the decline in pulmonary function as measured by FVC, compared with a placebo, over the period of 52 weeks. Those two publications endure to this day as the greatest milestone in the evolution of the therapeutic approach to pulmonary interstitial diseases. For many years, combination therapy with corticosteroids and azathioprine, based on the mistaken context of persistent inflammation leading to fibrosis, and the subsequent addition of $\mathrm{N}$-acetylcysteine, based on the idea that oxidative stress is a component of anomalous healing after alveolar epithelial damage with consequent extracellular matrix deposition and fibrosis progression, was used indiscriminately, which invariably led to the progression of the disease and to a mean survival rate of three years after diagnosis. ${ }^{(9,10)}$ Subsequently, it was shown that this therapy did not provide any benefits in patients with IPF, rather causing significant adverse effects because the triple-therapy arm of the study had to be stopped prematurely due to a significant number of hospitalizations and deaths compared with the other two therapeutic arms of the study (i.e. $\mathrm{N}$-acetylcysteine and placebo). ${ }^{(11)}$ Although the use of pirfenidone was approved in 2008 in Japan and 2011 in Europe, it was only after the study conducted by King Jr et al. ${ }^{(7)}$ that its use was considered worldwide and approved in most countries, simultaneously with the use of nintedanib. At that time, patients finally had access to medications that could slow the progression of their disease, which resulted in longer survival with better quality of life, as well as greater preservation of their autonomy.

After the initial enthusiasm, doubts arose as to whether the combined use of pirfenidone and nintedanib would be beneficial to all patients with a diagnosis of IPF and whether they should be prescribed immediately after diagnosis, especially in patients that are still only mildly symptomatic and have preserved lung function. The data stratification from those trials ${ }^{(7,8)}$ left no doubt about the benefit of either drug, regardless of patient characteristics (i.e. age and gender), as well as independently of the stage of the disease according to FVC and DLCO values. ${ }^{(12)}$ Effectively, when comparing patients with an FVC > 90\% of the predicted value with those with lower values, it was found that the decline in pulmonary function was similar. The same result was achieved with the use of pirfenidone in patients with FVC $>80 \%$ of the predicted value compared with those with an FVC $<80 \%$ of the predicted value. These results support the benefit of early treatment in order to decelerate the progression of the disease as early as possible, which would require an equally early diagnosis. ${ }^{(13,14)}$ Similarly, regarding patients in more advanced stages of the disease (FVC $<50 \%$ of the predicted value), it was shown that they had a slower decline in pulmonary function, at a value that overlapped with that of patients at a better functional stage, after starting antifibrotic therapy. ${ }^{(15)}$ After an initial period during which treated patients typically presented FVC between $50 \%$ and $80 \%$ of the predicted value, according to the inclusion criteria of some of the reported clinical trials, the results led to the current standard of prescribing antifibrotic therapy for any patient diagnosed with IPF and instituting that therapy as soon as possible. ${ }^{(16,17)}$ Recent studies on the prolonged use (for up to four years) of pirfenidone and nintedanib ${ }^{(18,19)}$ have reported that the effect of those medications was maintained over the study period, given that the decline in FVC per year was of equal dimension. The question at hand is mainly related to the potential effect that those two medications have on other chronic progressive fibrotic diseases, especially following the recent publication of results suggesting that they have the identical effect of decreasing the degree of functional deterioration. ${ }^{20,21)}$ 
In a real-life study published in this issue of the JBP, Pereira et al.(22) evaluated a select group of 57 IPF patients who benefited from a program providing free access to treatment with nintedanib, describing the safety and tolerability of the medication. The patients included in the study were diagnosed mainly based on imaging examinations, only $22.8 \%$ having undergone a surgical lung biopsy, which is in line with data in the literature. Regarding adverse effects, and corroborating previously published studies, ${ }^{(23,24)}$ gastrointestinal symptoms, especially diarrhea, were the most frequently reported in $78.9 \%$ of patients, being considered severe in $22.2 \%$ of the patients. In contrast, an increase in liver function parameters was observed in only 1 patient. Adverse effects were largely responsible for permanent discontinuation of treatment in 20 patients (35.1\%) and dosage reduction in 21 (36.8\%). Continued publication of real-life studies from various geographical regions of the world, such as the present study, ${ }^{(22)}$ has been central to acquiring an accurate understanding of the tolerance profile of antifibrotics.

In conclusion, in the current state of the art, the differential diagnosis of IPF should be made as accurately and as early as possible so that patients may have the benefit of antifibrotic therapy when they are still in an early stage of the disease.

\section{REFERENCES}

1. Raghu G, Collard HR, Egan JJ, Martinez FJ, Behr J, Brown KK, et al. An official ATS/ERS/JRS/ALAT statement: idiopathic pulmonary fibrosis: evidence-based guidelines for diagnosis and management. Am J Respir Crit Care Med. 2011;183(6):788-824. https://doi.org/10.1164/ rccm.2009-040GL

2. Robalo Cordeiro C, Campos P, Carvalho L, Campainha S, Clemente $S$, Figueiredo $L$, et al. Consensus document for the diagnosis and treatment of idiopathic pulmonary fibrosis: Joint Consensus of Sociedade Portuguesa de Pneumologia, Sociedade Portuguesa de Radiologia e Medicina Nuclear e Sociedade Portuguesa de Anatomia Patológica. Rev Port Pneumol (2006). 2016;22(2):112-22. https://doi. org/10.1016/j.rppnen.2016.01.003

3. Travis WD, Costabel U, Hansell DM, King TE Jr, Lynch DA, Nicholson AG, et al. An official American Thoracic Society/European Respiratory Society statement: Update of the international multidisciplinary classification of the idiopathic interstitial pneumonias. Am J Respir Crit Care Med. 2013;188(6): 733-48. https://doi.org/10.1164/rccm.201308 1483ST

4. Walsh SLF, Wells AU, Desai SR, Poletti V, Piciucchi S, Dubini A, et al Multicentre evaluation of multidisciplinary team meeting agreement on diagnosis in diffuse parenchymal lung disease: a case-cohort study. Lancet Respir Med. 2016;4(7):557-565. https://doi.org/10.1016/S2213 2600(16)30033-9

5. Lynch DA, Sverzellati N, Travis WD, Brown KK, Colby TV, Galvin JR, et al. Diagnostic criteria for idiopathic pulmonary fibrosis: a Fleischner Society White Paper. Lancet Respir Med. 2018:6(2):138-153. https:// doi.org/10.1016/S2213-2600(17)30433-2

6. Hortense AB, Santos MKD, Wada D, Fabro AT, Lima M, Rodrigues $S$, et al. Familial pulmonary fibrosis: a heterogeneous spectrum of presentations. J Bras Pneumol. 2019;45(5):e20180079. https://doi. org/10.1590/1806-3713/e20180079

7. King TE Jr, Bradford WZ, Castro-Bernardini S, Fagan EA, Glaspole I, Glassberg MK, et al. A phase 3 trial of pirfenidone in patients with idiopathic pulmonary fibrosis. N Engl J Med. 2014;370(22):2083-92. https://doi.org/10.1056/NEJMoa1402582

8. Richeldi L, du Bois RM, Raghu G, Azuma A, Brown KK, Costabe $U$, et al. Efficacy and safety of nintedanib in idiopathic pulmonary fibrosis. N Engl J Med. 2014;370(22):2071-82. https://doi.org/10.1056/ NEJMoa1402584

9. King TE Jr, Pardo A, Selman M. Idiopathic pulmonary fibrosis. Lancet. 2011;378(9807):1949-61. https://doi.org/10.1016/S0140 6736(11)60052-4

10. Soares Pires F, Caetano Mota P, Melo N, Costa D, Jesus JM, Cunha R et al. Idiopathic pulmonary fibrosis-clinical presentation, outcome and baseline prognostic factors in a Portuguese cohort. Rev Port Pneumol. 2013;19(1):19-27. https://doi.org/10.1016/j.rppnen.2012.06.003

11. Idiopathic Pulmonary Fibrosis Clinical Research Network, Raghu G, Anstrom KJ, King TE Jr, Lasky JA, Martinez FJ. Prednisone azathioprine, and $\mathrm{N}$-acetylcysteine for pulmonary fibrosis. $\mathrm{N}$ Engl $\mathrm{J}$ Med. 2012;366(21):1968-77. https://doi.org/10.1056/NEJMoa1113354

12. Noble PW, Albera C, Bradford WZ, Costabel U, du Bois RM, Fagan EA et al. Pirfenidone for idiopathic pulmonary fibrosis: analysis of pooled data from three multinational phase 3 trials. Eur Respir $\mathrm{J}$. 2016;47(1):243-53. https://doi.org/10.1183/13993003.00026-2015
13. Kolb M, Richeldi L, Behr J, Maher TM, Tang W, Stowasser S, et al. Nintedanib in patients with idiopathic pulmonary fibrosis and preserved lung volume. Thorax. 2017;72(4):340-346. https://doi.org/10.1136/ thoraxinl-2016-208710

14. Albera C, Costabel U, Fagan EA, Glassberg MK, Gorina E Lancaster $L$, et al. Efficacy of pirfenidone in patients with idiopathic pulmonary fibrosis with more preserved lung function. Eur Respir $\mathrm{J}$ 2016;48(3):843-51. https://doi.org/10.1183/13993003.01966-2015

15. Wuyts WA, Kolb M, Stowasser S, Stansen W, Huggins JT, Raghu G. First Data on Efficacy and Safety of Nintedanib in Patients with Idiopathic Pulmonary Fibrosis and Forced Vital Capacity of $\leq 50 \%$ of Predicted Value. Lung. 2016;194(5):739-43. https://doi.org/10.1007/ s00408-016-9912-1

16. Raghu G, Rochwerg B, Zhang Y, Garcia CA, Azuma A, Behr J, et al. An Official ATS/ERS/JRS/ALAT Clinical Practice Guideline: Treatment of Idiopathic Pulmonary Fibrosis. An Update of the 2011 Clinical Practice Guideline. Am J Respir Crit Care Med. 2015;192(2):e3-19. https://doi. org/10.1164/rccm.201506-1063ST

17. Robalo-Cordeiro C, Campos $P$, Carvalho $L$, Borba $A$, Clemente $S$ Freitas $S$, et al. Idiopathic pulmonary fibrosis in the era of antifibrotic therapy: Searching for new opportunities grounded in evidence. Rev Port Pneumol (2006). 2017:23(5):287-293 https://doi.org/10.1016/j. rppnen.2017.05.005

18. Cottin V, Koschel D, Günther A, Albera C, Azuma A, Sköld CM et al. Long-term safety of pirfenidone: results of the prospective observational PASSPORT study. ERJ Open Res. 2018:4(4). pii: 00084 2018. https://doi.org/10.1183/23120541.00084-2018

19. Crestani B, Huggins JT, Kaye M, Costabel U, Glaspole I, Ogura T, et al. Long-term safety and tolerability of nintedanib in patients with idiopathic pulmonary fibrosis: results from the open-label extension study, INPULSIS-ON. Lancet Respir Med. 2019;7(1):60-68. https://doi. org/10.1016/S2213-2600(18)30339-4

20. Distler O, Highland KB, Gahlemann M, Azuma A, Fischer A, Mayes MD, et al. Nintedanib for Systemic Sclerosis-Associated Interstitia Lung Disease. N Engl J Med. 2019;380(26):2518-2528. https://doi. org/10.1056/NEJMoa1903076

21. Flaherty KR, Wells AU, Cottin V, Devaraj A, Walsh SLF, Inoue Y, et al Nintedanib in Progressive Fibrosing Interstitial Lung Diseases. N Eng J Med. 2019 Sep 29. [Epub ahead of print] https://doi.org/10.1056/ NEJMoa1908681

22. Pereira CAC, Baddini-Martinez JA, Baldi BG, Jezler SFO, Rubin AS Alves RLR, et al. Safety and tolerability of nintedanib in patients with idiopathic pulmonary fibrosis in Brazil. J Bras Pneumol. 2019;45(5):e20180414

23. Tzouvelekis A, Karampitsakos T, Kontou M, Granitsas A, Malliou I. Anagnostopoulos A et al. Safety and efficacy of nintedanib in idiopathic pulmonary fibrosis: A real-life observational study in Greece. Pulm Pharmacol Ther. 2018;49:61-66. https://doi.org/10.1016/j. pupt.2018.01.006

24. Bargagli E, Piccioli C, Rosi E, Torricelli E, Turi L, Piccioli E, et al. Pirfenidone and Nintedanib in idiopathic pulmonary fibrosis: Real-life experience in an Italian referral centre. Pulmonology. 2019;25(3):149153. https://doi.org/10.1016/j.pulmoe.2018.06.003 